\title{
TREND ON THE LACK OF PRIVATE OPEN SPACE IN SEVERAL CONTIGUOUS HOUSING IN SIDOARJO
}

\author{
Christina E. Mediastika \\ Department of Architecture, Petra Christian University \\ Indonesia \\ e-mail: eviutami@petra.ac.id
}

\begin{abstract}
Limited proportion between built area and open space of house-lots in housing district seems to become trend in some housing. Within period of occupancy, houseowners are continuously requiring more rooms. A common solution is to transform available open space in the lot into building. Several contiguous housing in Sidoarjo Regency, comprises of low-to-medium and medium-to high housing types was studied to learn on the trend. The study concluded that definition of low-to-medium and medium-to-high class housing was a correct term here. In average, respondents had duration of occupancy of 15 to 20 years and most were undertaken housing extension. From 83 respondents out of 170 suspected houses of having insufficient open space was significantly proved that the extension leaved open space toward 0\%. This means that lack of private open space is a factual trend here. When lack of open space is a trend, we may easily suspect that green open space is in similar term.

Interesting phenomenon was found that apart from good level of early and prior awareness on the necessity of open space, average respondents had significantly lower early knowledge on the importance of open space especially in term of providing rainwater absorption bed. Their knowledge increased gradually currently. However, their current knowledge was still lower than their awareness. This finding is expected to be useful in planning further stage of community outreach to give informal lecture among community due to actual procedure in fixing open space inexistence, especially to further generation.
\end{abstract}

Keywords: house-lot, house extension, open space

\begin{abstract}
ABSTRAK
Proporsi yang terbatas antara area terbangun dan ruang terbuka pada kapling rumah di distrik perumahan tampaknya menjadi tren di beberapa perumahan. Dalam periode hunian, pemilik rumah terus membutuhkan lebih banyak ruang. Solusi umum adalah dengan mengubah ruang terbuka yang tersedia pada kapling menjadi bangunan. Beberapa perumahan yang berdekatan di Kabupaten Sidoarjo, terdiri
\end{abstract}


dari tipe perumahan rendah ke menengah dan menengah ke atas dipelajari untuk mengetahui tren. Studi ini menyimpulkan bahwa definisi perumahan kelas rendah ke menengah dan menengah ke atas adalah istilah yang benar di sini. Rata-rata, responden memiliki durasi hunian 15 sampai 20 tahun dan sebagian besar melakukan perluasan rumah. 83 responden dari 170 rumah yang diduga memiliki ruang terbuka yang cukup signifikan membuktikan bahwa perluasan meninggalkan ruang terbuka hingga 0\%. Ini berarti bahwa kurangnya ruang terbuka pribadi adalah tren faktual di sini. Ketika kurangnya ruang terbuka menjadi tren, kita dapat dengan mudah menduga bahwa ruang terbuka hijau berada dalam kondisi yang sama.

Fenomena menarik ditemukan bahwa selain dari tingkat yang baik kesadaran awal dan sebelumnya tentang perlunya ruang terbuka, responden rata-rata memiliki pengetahuan awal yang secara signifikan lebih rendah tentang pentingnya ruang terbuka terutama dalam hal menyediakan tempat penyerapan air hujan. Pengetahuan mereka meningkat secara bertahap sekarang. Namun, pengetahuan mereka saat ini masih lebih rendah dari kesadaran mereka. Temuan ini diharapkan dapat berguna dalam perencanaan tahap lebih lanjut dari penjangkauan masyarakat untuk memberikan kuliah informal di antara masyarakat karena tidak adanya prosedur yang sebenarnya dalam memperbaiki ruang terbuka, terutama untuk generasi selanjutnya.

Kata Kunci: kapling rumah, perluasan rumah, ruang terbuka

\section{INTRODUCTION}

Demand on more and bigger room within house has triggered house-owner to extend their house both horizontally and vertically. Unprepared building sub-structure to bear additional upper structure of two-storey or more buildings leads to horizontal extension as a trend. Horizontal building extension on limited house-lots of housing resulted in insufficient open space. This seems becoming trends in Indonesian house-lots. The trend was suspected as a cause of limited awareness and knowledge among house-owners on the necessity of green open space or simply opens space around houses.

House with sufficient open space will gain many benefits, such as daylighting and natural ventilation for most of its inner rooms. When the open space is green, it will also provide absorption bed for rainwater harvesting which is constantly redundant during rainy season in Indonesia. House without sufficient open space has significant contribution to local puddle. When houses with insufficient open space are majority in a housing region more puddles toward flood are likely to happen.

Issue and discussion on green open space or open space within private property is very limited. We mostly discuss on the necessity of public green open space and slightly disregard the benefits of private green open space or just open space (OS). A green OS in a private lot is never been any bigger than that of public OS. But, a multiple effects of this insignificant dimension will play a role on the availa- 
bility of sufficient open space for urban region. That is, a research to study the main cause of lack of private OS is reported here.

\section{Objective}

The study was aimed to learn on how house-owners having decision on extending their house. In detail the study would see whether there is any correlation among buildings' extension and duration of occupancy, economic class or income, awareness and knowledge on the necessity of private OS. The finding will be use to educate younger generation on the importance of OS through informal classes.

\section{THEORY / RESEARCH METHODS}

Study by Lacy (1990) has reported that clustered houses with protected OS were appreciated higher by market than those of single conventional housing with larger private yards. This case might not be similar to that in Indonesia. It is suspected that housing with both public open space and sufficient private OS is more appreciated and expected here. This opinion is supported by Connel and Walls (2005) who revealed that OS values are case study-specific. Particular OS area or set of areas is unique to a particular region and time period. Notions of beneficial effects of nearby green space have persisted throughout history, especially to improve people's health and well-being by providing restoration from stress and mental fatigue (Groenewegen, 2006). A research comparing residents with a view of urban greenery to residents without such view showed that those with view gain better well-being (Kaplan, 2001). Moreover, a research has shown that views of nature can improve feelings of neighborhood safety and even lead to decreases in aggression and crime rates (Kuo and Sullivan 2001 a and 2001b). With these so many benefits, it is expected that house-owners are aware and possess knowledge on how OS shall be provided within house-lots. Awareness and knowledge is expected to be effective instrument to fix the trend.

\section{Research Methods}

The study was conducted as quantitative field survey. Questionnaire was developed as an instrument to collect the data. Respondents were limited to house-owners of several contiguous housing in Sidoarjo, Indonesia. It was Wisma Beringin, Kemendung Indah and Citra Harmoni (Figure 1, 2, and 3). The first two housing was expected to represent low-to-medium class housing, whilst the last was for medium-tohigh class housing. The housings were selected based on the constant issue of the existence of local puddle during rainy season. Borderless-contiguous mixed of lowto-medium and medium-to-high class housings was also an issue to determine the research site. Richness of housing types will benefit the study to learn whether monetary factor exists toward decision on building extension. 


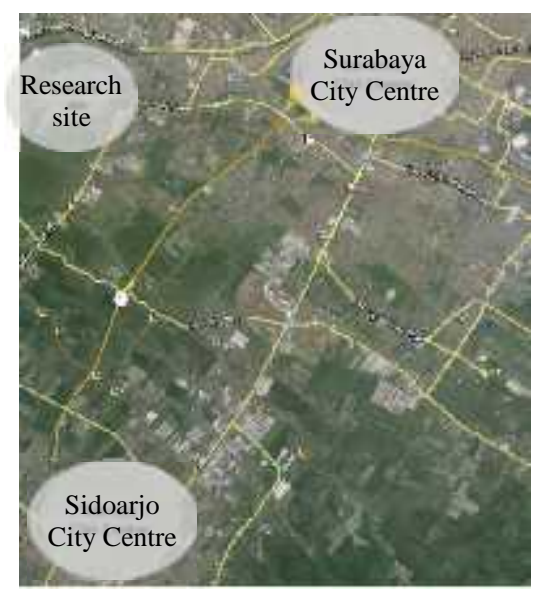

Figure 1. Research Site

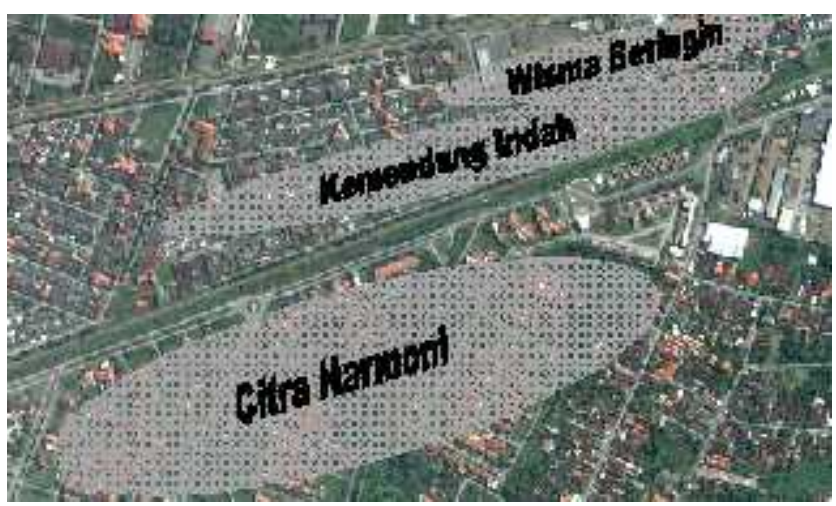

Figure 2. Contiguous Housing of Research Site

The questionnaire was developed using Likert's scale-like method, as the Likert's might not be use in full term. Likert's scale is a widely used method to study people's opinion on such issues. It usually scores from nethermost to uppermost, such as from "very disagree" to "very agree". It may be scaled from 1 to 5 or 1 to 7 for more detail. As this study was not merely learning on people's opinion, but more of studying on the causal effects of an action, the Likert's was modified to fit the expected data. However, the modification was developed as close as possible to the Likert's. 

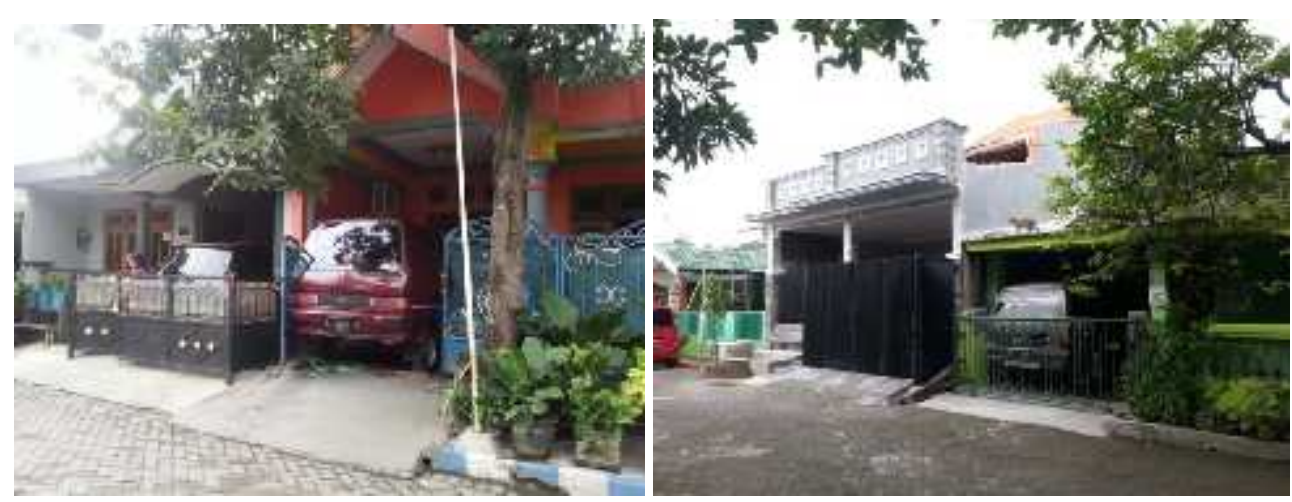

Figure 3. Examples of House in Kemendung Indah Residence with Full-Front Roofing The Roofing Exaggerates on to the Street Side

There were dependent and independent variables prior constructing the questionnaire refer to Table 1. The dependent was building extension on the house-lots, whilst the independents were duration of occupancy, monthly income, and early and current awareness and knowledge on the necessity of green OS. These variables were generated within a set of questions. Answers options were constructed based on easiness, as questionnaire was not interviewed but self-filled by respondents. Comprehensive instruction to fill and pick answers was written before the question lists and delivers orally during distribution. The self-filled method was selected upon time availability of the respondents. Most respondents spend their time working elsewhere and thus very limited time for enumerator to conduct interview. That is, self-filled method was considered more appropriate to gain as many as possible respondents. Checking for errors or bias answers were carried out during collection of filled questionnaires, so as to be directly confirmed to the associated respondent. It was 100 questionnaires distributed, and 83 were returned.

It is written on the questionnaire that the questionnaire was suggested to be completed by family-head to minimize error. In Indonesia, family-head usually husband/father or wife/mother. Options of answers were designed so as to be perceptible by various knowledge backgrounds. Prior to the main survey, pre-survey was conducted by distributing 5 questionnaires to those who were not respondents to be. From here some correction were made toward perfect questionnaire. The questionnaire was constructed sequentially. First was to gain personal data consist of position in family, age, income, and duration of occupancy. Second was to gain data of housing-lots consist of housing-lots dimension, early building dimension, and current building dimension. Current housing-lot was not asked considering that expansion of housing-lot was very rarely to happen. Third was confirmation on whether any expansion was done by respondents or by previous occupants. Forth was awareness and knowledge on the necessity of OS and the procedure to allocate it.

Variables of respondents' economical background was asked in term of respondents' monthly income, scaled from average of Indonesian lowest income to the possible highest income of the site. Age and duration of occupancy were constructed as opened-question to gain actual data rather than a closed question. Question of lot 
and housing dimension were also asked as opened questions for similar reason. The answers collected were then to be stratified in the analysis. Awareness and knowledge were asked as closed-question with option of answers was "was not aware" and "aware"; "do not possess knowledge" and "possess knowledge". Those who possess knowledge should continue to the next opened-question on how rainwater to be channeled. Each was scored 0 to 3 respectively. Information on questionnaire concepts and how variables were elaborated within questionnaire is presented in Table 1.

Table 1. Concept and Variables Determination

\begin{tabular}{|c|c|c|c|c|}
\hline No. Concept & Variables & Term & Answer options & Scores \\
\hline \multirow{6}{*}{$\begin{aligned} 1 & \text { "OS" } \\
& \text { determi- } \\
& \text { nants }(\mathrm{X})\end{aligned}$} & \multirow{6}{*}{$\begin{array}{l}\text { Duration of occupancy } \\
\left(\mathrm{X}_{1}\right)\end{array}$} & \multirow[t]{6}{*}{ n.a. } & a. $0-5$ years & 0 \\
\hline & & & b. $5.1-10$ years & 1 \\
\hline & & & c. $10.1-15$ years & 2 \\
\hline & & & d. $15.1-20$ years & 3 \\
\hline & & & e. 20.1-25 years & 4 \\
\hline & & & f. $>25.1$ years & 5 \\
\hline \multirow[t]{3}{*}{2} & \multirow[t]{3}{*}{$\begin{array}{l}\text { Building extension } \\
\left(\mathrm{X}_{2}\right)\end{array}$} & \multirow[t]{3}{*}{ n.a. } & $\begin{array}{l}\text { a. Extending with no re- } \\
\text { maining "OS" }\end{array}$ & 0 \\
\hline & & & $\begin{array}{l}\text { b. Extending with remain- } \\
\text { ing "OS" }\end{array}$ & 1 \\
\hline & & & c. No extension & 2 \\
\hline \multirow[t]{2}{*}{3} & \multirow{2}{*}{$\begin{array}{l}\text { "OS" to building ratio } \\
\text { (X3) }\end{array}$} & \multirow[t]{2}{*}{ n.a. } & a. $<40 \% *$ & 0 \\
\hline & & & b. $\geq 40 \%$ & 1 \\
\hline \multirow[t]{5}{*}{4} & \multirow[t]{5}{*}{ Monthly income $\left(\mathrm{X}_{4}\right)$} & \multirow[t]{5}{*}{ n.a. } & a. $<2$ million IDR & 0 \\
\hline & & & b.2-5 million IDR & 1 \\
\hline & & & c. 5.1-10 million IDR & 2 \\
\hline & & & d.10.1-15 million IDR & 3 \\
\hline & & & e.> 15.1 million IDR & 4 \\
\hline \multirow[t]{2}{*}{5} & \multirow[t]{4}{*}{ Awareness $\left(\mathrm{X}_{5}\right)$} & \multirow[t]{2}{*}{ Early } & a. Was not aware & 0 \\
\hline & & & b.Aware & 1 \\
\hline \multirow[t]{2}{*}{6} & & \multirow[t]{2}{*}{ Current } & a. Was not aware & 0 \\
\hline & & & b.Aware & 1 \\
\hline \multirow[t]{2}{*}{7} & \multirow[t]{4}{*}{ Knowledge $\left(\mathrm{X}_{6}\right)$} & Early & a. Do not posses knowledge & 0 \\
\hline & & & b.Posses Knowledge & 1 \\
\hline \multirow[t]{2}{*}{8} & & \multirow[t]{2}{*}{ Current } & a. Do not posses knowledge & 0 \\
\hline & & & b.Posses Knowledge & 1 \\
\hline
\end{tabular}

Note: $* 40 \%$ was set as benchmark due to generally used of ideal OS to building ratio.

The questionnaire was distributed half randomly, as this was intentionally studying houses with suspected insufficient OS within lots. In the low-to-medium housing, it was found that from the entire 150 houses; 90 house-facades indicated that open space was insufficient. Fifty two of the "insufficient OS" were surveyed. In the medium-to-high housing, questionnaires distribution was narrowed to housing block of small lots, as those with large lots appeared to have large OS and thus did not fit the research scope. From the entire 160 small-lots houses, it was found that 
80 houses indicated insufficient OS within lots. Thirty one of the "insufficient OS" were surveyed.

\section{RESULTS AND DISCUSSION}

Table 2. Summary of Data's Statistical Review

\begin{tabular}{|c|c|c|c|c|c|c|c|c|c|}
\hline $\begin{array}{l}\text { Statistic- } \\
\text { al term }\end{array}$ & $\begin{array}{c}\text { Dura- } \\
\text { tion } \\
\text { of } \\
\text { occu- } \\
\text { pancy }\end{array}$ & $\begin{array}{l}\text { Building } \\
\text { exten- } \\
\text { sion }\end{array}$ & $\begin{array}{c}\text { Early } \\
\text { OS to } \\
\text { building } \\
\text { ratio }\end{array}$ & $\begin{array}{l}\text { Current } \\
\text { OS to } \\
\text { building } \\
\text { ratio }\end{array}$ & $\begin{array}{l}\text { In- } \\
\text { come }\end{array}$ & $\begin{array}{l}\text { Early } \\
\text { aware- } \\
\text { ness on } \\
\text { OS ne- } \\
\text { cessity }\end{array}$ & $\begin{array}{c}\text { Cur- } \\
\text { rent } \\
\text { aware- } \\
\text { ness on } \\
\text { OS ne- } \\
\text { cessity }\end{array}$ & $\begin{array}{c}\text { Early } \\
\text { know- } \\
\text { ledge on } \\
\text { OS ne- } \\
\text { cessity }\end{array}$ & $\begin{array}{l}\text { Current } \\
\text { know- } \\
\text { ledge on } \\
\text { OS ne- } \\
\text { cessity }\end{array}$ \\
\hline Mean & 2.27 & 0.81 & 0.75 & 0.03 & 1.42 & 0.82 & 0.86 & 0.11 & 0.43 \\
\hline $\begin{array}{l}\text { Standard } \\
\text { Error }\end{array}$ & 0.22 & 0.04 & 0.05 & 0.02 & 0.12 & 0.04 & 0.04 & 0.03 & 0.05 \\
\hline Median & 2.00 & 1.00 & 1.00 & 0.00 & 1.00 & 1.00 & 1.00 & 0.00 & 0.00 \\
\hline Mode & 0.00 & 1.00 & 1.00 & 0.00 & 1.00 & 1.00 & 1.00 & 0.00 & 0.00 \\
\hline $\begin{array}{l}\text { Standard } \\
\text { Deviation }\end{array}$ & 1.98 & 0.40 & 0.44 & 0.15 & 1.06 & 0.39 & 0.35 & 0.31 & 0.50 \\
\hline $\begin{array}{l}\text { Sample } \\
\text { Variance }\end{array}$ & 3.90 & 0.16 & 0.19 & 0.02 & 1.12 & 0.15 & 0.13 & 0.10 & 0.25 \\
\hline Kurtosis & -1.55 & 0.53 & -0.68 & 38.73 & -0.05 & 0.88 & 2.29 & 4.69 & -1.97 \\
\hline Skewness & 0.16 & -1.59 & -1.16 & 6.30 & 0.59 & -1.69 & -2.06 & 2.57 & 0.27 \\
\hline Range & 5.00 & 1.00 & 1.00 & 1.00 & 4.00 & 1.00 & 1.00 & 1.00 & 1.00 \\
\hline Minimum & 0.00 & 0.00 & 0.00 & 0.00 & 0.00 & 0.00 & 0.00 & 0.00 & 0.00 \\
\hline Maximum & 5.00 & 1.00 & 1.00 & 1.00 & 4.00 & 1.00 & 1.00 & 1.00 & 1.00 \\
\hline Sum & $\begin{array}{r}188.0 \\
0\end{array}$ & 67.00 & 62.00 & 2.23 & 118.00 & 68.00 & 71.00 & 9.00 & 36.00 \\
\hline Count & 83.00 & 83.00 & 83.00 & 83.00 & 83.00 & 83.00 & 83.00 & 83.00 & 83.00 \\
\hline $\begin{array}{l}\text { Largest } \\
\text { (1) }\end{array}$ & 5.00 & 1.00 & 1.00 & 1.00 & 4.00 & 1.00 & 1.00 & 1.00 & 1.00 \\
\hline $\begin{array}{l}\text { Smallest } \\
\text { (1) }\end{array}$ & 0.00 & 0.00 & 0.00 & 0.00 & 0.00 & 0.00 & 0.00 & 0.00 & 0.00 \\
\hline $\begin{array}{l}\text { Confi- } \\
\text { dence } \\
\text { Level } \\
(95 \%)\end{array}$ & 0.43 & 0.09 & 0.10 & 0.03 & 0.23 & 0.08 & 0.08 & 0.07 & 0.11 \\
\hline & 0.85 & 0.60 & 0.58 & -0.03 & 0.09 & 0.25 & 0.27 & 0.31 & 0.40 \\
\hline r table & & 0.22 & 0.22 & 0.22 & 0.22 & 0.22 & 0.22 & 0.22 & 0.22 \\
\hline Validity & valid & valid & valid & not valid & $\begin{array}{r}\text { not } \\
\text { valid }\end{array}$ & valid & valid & valid & valid \\
\hline Reliability & 0.43 & 0.43 & 0.43 & 0.43 & 0.43 & 0.43 & 0.43 & 0.43 & 0.43 \\
\hline
\end{tabular}

It was 100 questionnaires distributed proportionally among selected housings, and 83 were returned. This was also in good proportion between the low-to medium 
and the medium-to-high class housing. That is 52 of low-to-medium cost housing and 31 of medium-to-high class housing. The data extracted from questionnaire result was reviewed statistically and the result is presented in Table 2. Data's validity was tested using correlation test, and was found that 2 questions were not valid and should not be used for further analysis. The reliability was tested using Cronbach's alpha and was resulted 0.43 which is considered quite reliable (Urdan, 2010).

By Table 1 and Table 2, we may learn that average duration of occupancy is 2.27. Converted to answer's options, this value is duration of occupancy between 10.1 to 15 years. Discrepancy of duration of occupancy between low-to-medium cost housing and medium-to-high cost housing is presented in detail by Figure 4. As the medium-to-high class housing was relatively newer in operation (15 years later), residents were also mostly newer than those of the low-to-medium class housing, which was inhabited approximately 28 years ago.

By Table 1 and Table 2 we learn that monthly income variable should be disregarded for further analysis in association to other variables as it is not valid, but by Figure 5, we learn that what was suspected as to be low-to medium and medium-tohigh class housing was correct by factor of income.

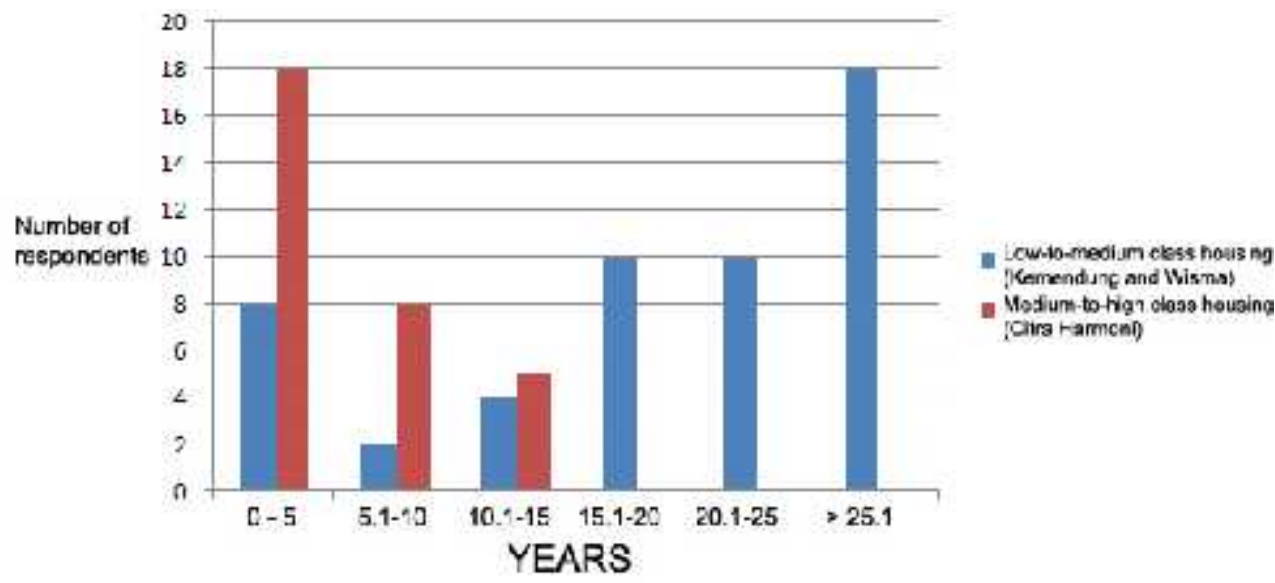

Figure 4. Duration of Occupancy between Low-to-Medium and Medium-to-High Cost Housing

By Table 2, we learn that current OS to building ratio is not valid in statistical term, this was suspected to be caused by the 0 score which was spread evenly throughout the data. This term is supported by Figure 6 that describes the average and the mode of early OS to building ratios were 0.75 and 1.00 (associated to Table 1) which is toward sufficient OS. On the opposite, both average and mode of current OS to building ratios were 0.03 and 0.00 . This is made clearer by Figure 7 that presents factual data of OS to building ratio in percentage $(\%)$. Within earlier occupancy, it was $50 \%$ in average which then sharply descend to $0 \%$ all. 


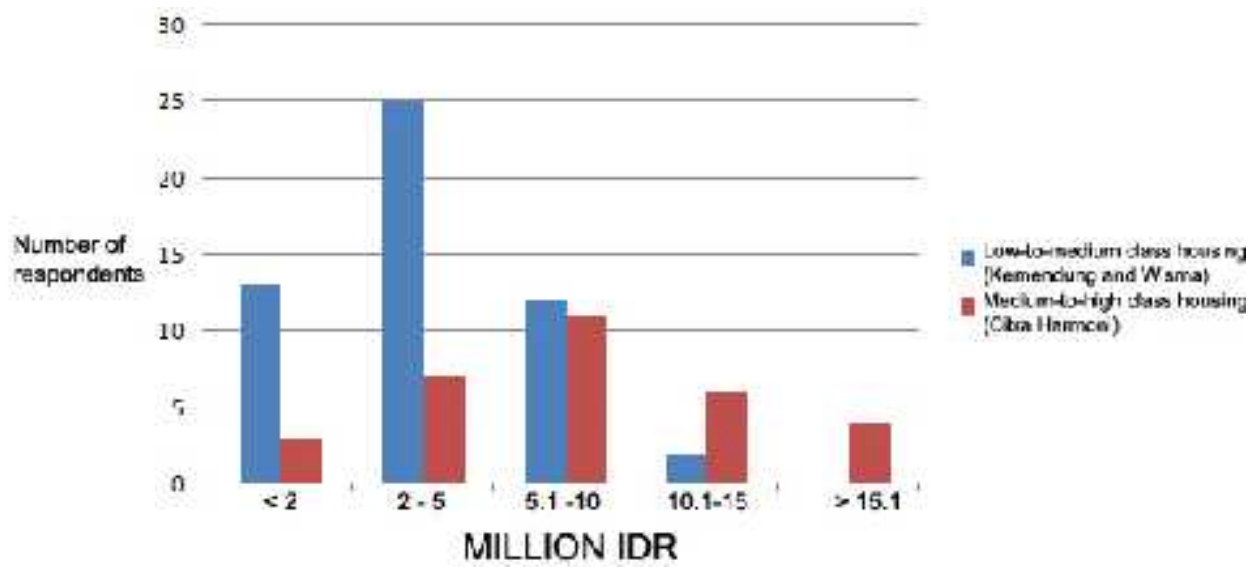

Figure 5. Monthly Income between Low-to-Medium and Medium-to-High Cost Housing

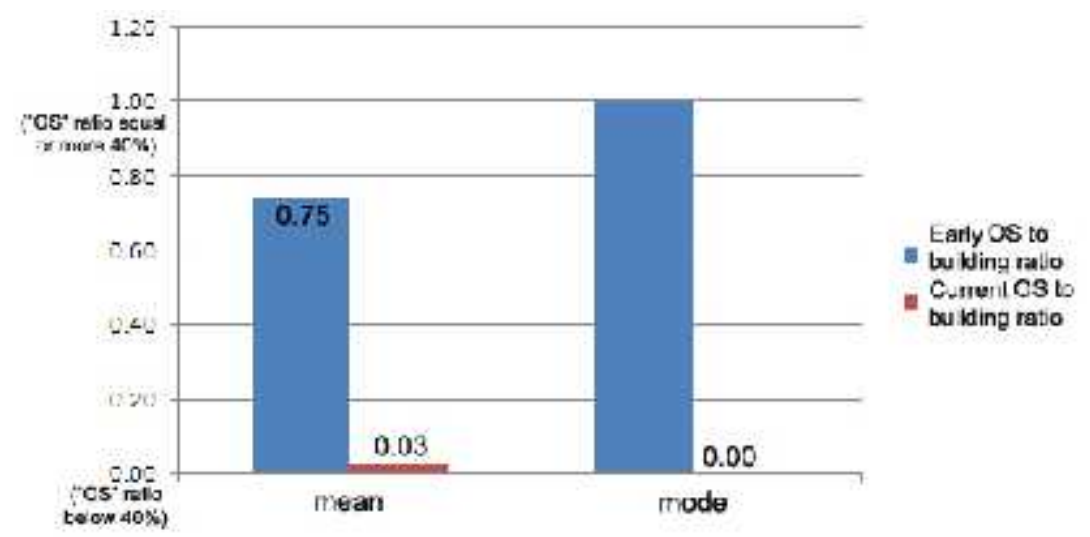

Figure 6. OS to Building Ratio of Early and Current

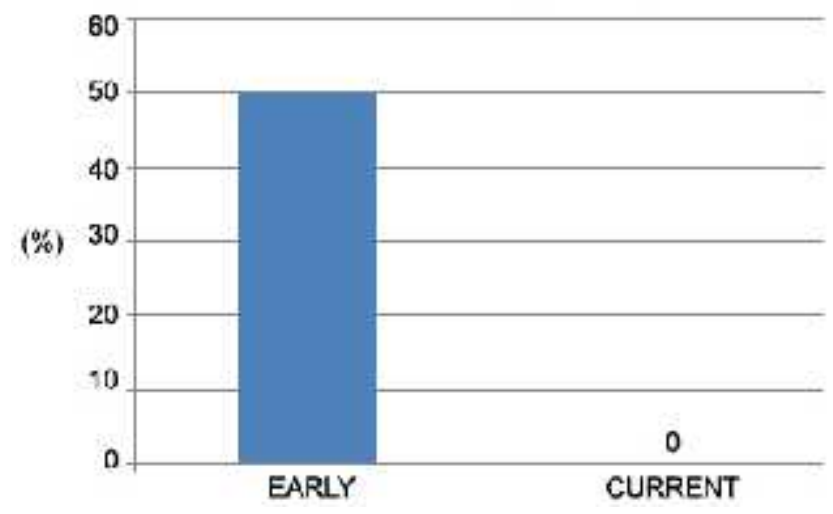

Figure 7. OS to Building Ratio of Early and Current in Actual Percentage 
On the awareness point of view, we may be happy to learn that in average, respondents were having good score toward awareness on the necessity of OS (Figure 8). However from knowledge point of view, we learn on something slightly worse. Both early and current knowledge was of lower score than the awareness. The average of current knowledge ascends from early knowledge, but the mode was constantly at 0 score (Figure 9).

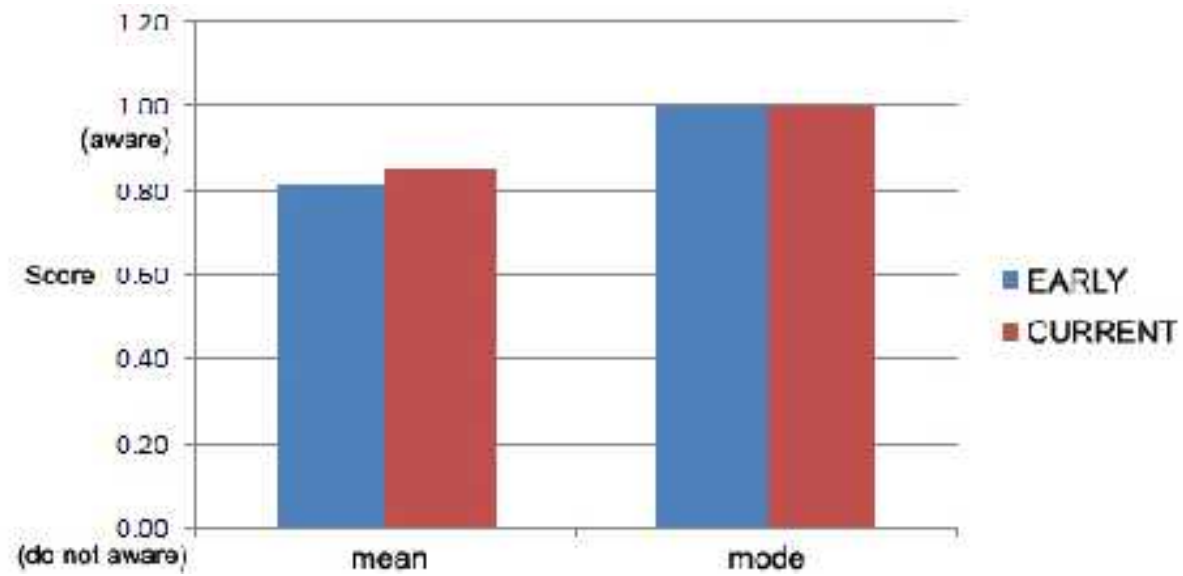

Figure 8. Respondents' Awareness of Early and Current

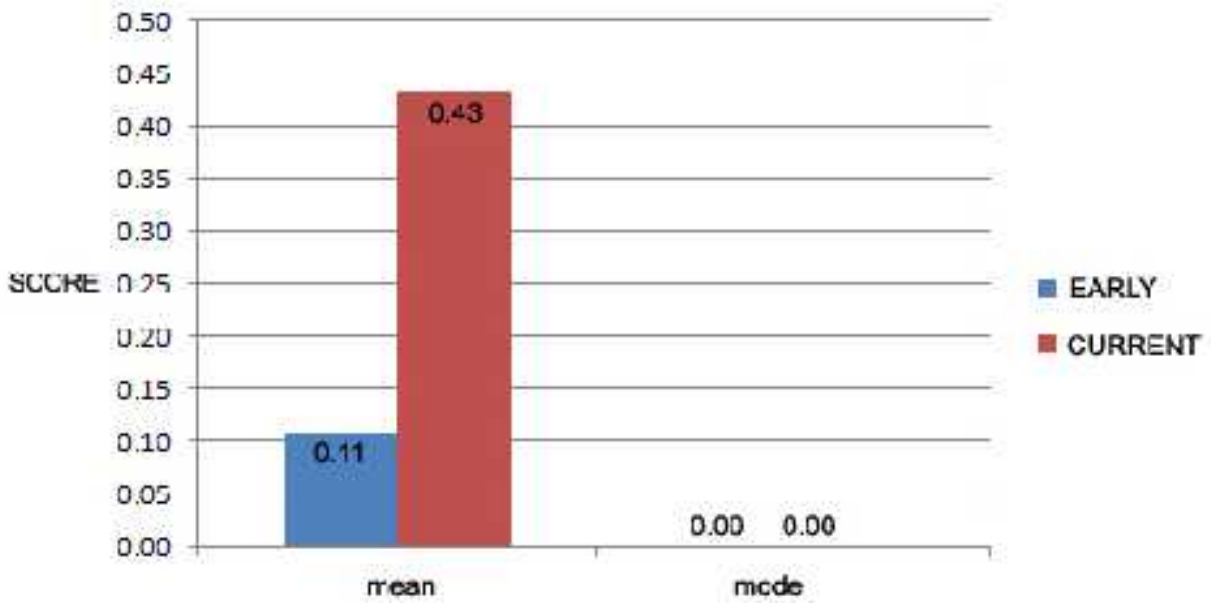

Figure 9. Respondents' Knowledge of Early and Current

Relationship of duration of occupancy and other variables may be studied using Table 3. In total, we see that building extension occurred more to those with longer occupancy period. From early OS to building ratio point of view, we learn that those with shorter occupancy period having lower ratio. This may mean that duration of occupancy do not always correlate to insufficient OS. From current OS to building ratio point of view, we see that insufficient OS happened in all period of occupancy. Early awareness and current awareness remain similar in all period of 
occupancy. From knowledge point of view, those of shortest period of occupancy seemed to be not having early knowledge due to necessity of OS. Later, the knowledge seemed to be evenly developed, with the highest point is at those of 15.1 to 20 years duration of occupancy.

Table 3. Duration of Occupancy Associated with Other Variables

\begin{tabular}{cccccccc}
\hline $\begin{array}{c}\text { Duration } \\
\text { of occu- } \\
\text { pancy } \\
\text { (years) }\end{array}$ & $\begin{array}{c}\text { Building } \\
\text { extension }\end{array}$ & $\begin{array}{c}\text { Early OS } \\
\text { to building } \\
\text { ratio }\end{array}$ & $\begin{array}{c}\text { Current } \\
\text { OS to } \\
\text { building } \\
\text { ratio }\end{array}$ & $\begin{array}{c}\text { Early } \\
\text { awareness }\end{array}$ & $\begin{array}{c}\text { Current } \\
\text { awareness }\end{array}$ & $\begin{array}{c}\text { Early } \\
\text { knowledge knowledge }\end{array}$ & $\begin{array}{c}\text { Current } \\
\text { - } 5\end{array}$ \\
\hline 0.62 & 0.58 & 0.04 & 0.73 & 0.77 & 0.00 & 0.27 \\
$5.1-10$ & 0.60 & 0.40 & 0.01 & 0.90 & 0.90 & 0.10 & 0.30 \\
$10.1-15$ & 0.78 & 0.89 & 0.11 & 0.78 & 0.89 & 0.11 & 0.44 \\
$15.1-20$ & 1.00 & 0.80 & 0.00 & 1.00 & 0.90 & 0.20 & 0.70 \\
$20.1-25$ & 1.00 & 0.90 & 0.00 & 0.90 & 0.90 & 0.10 & 0.60 \\
$>25.1$ & 1.00 & 1.00 & 0.00 & 0.78 & 0.89 & 0.22 & 0.50 \\
\hline
\end{tabular}

By Figure 10, we may learn that there was some disparities existed between low-to-medium and medium-to-high class housing. In most issues, those of low-tomedium class possess higher score than those of medium-to-high class housing. However, the disparities is insignificant, with issue of early OS, early knowledge and current knowledge are exception. Figure 10 reveals that medium-to-high class housing possesses significant lesser OS than medium-to-high class. The low-tomedium class housing also possess significant higher early and current knowledge.

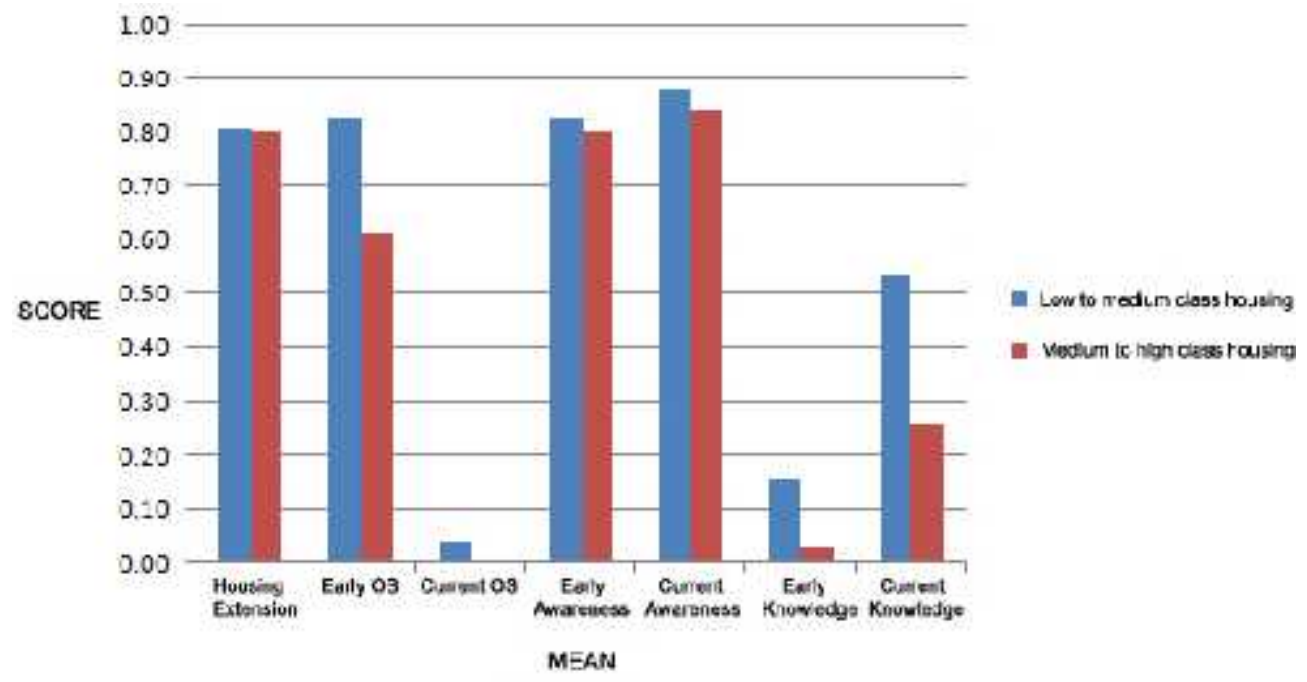

Figure 10. Disparities between Low-to-Medium and Medium-to-High Class Housing 


\section{CONCLUSIONS}

This study concluded that definition of low-to-medium and medium-to-high class housing was a correct term here, based only on respondents' monthly income. Disparities between the two were existed regarding issue of early OS, early knowledge, and current knowledge. Eighty three respondents out of 170 (almost 50\%) houses that were suspected having insufficient OS also proved here. This finding may lead to further finding that housing expansion with lack of OS is a trend here. When lack of OS was a trend, we may easily suspect that green OS was of similar term.

Interesting phenomenon was found that apart from good level of early and prior awareness, average respondents were having significantly lower knowledge. Their knowledge increased gradually currently. Sadly, their current knowledge was still lower than their awareness. This finding is expected to be useful to plan further action of community outreach to informally educate communities due to actual procedure of fixing OS inexistence, especially to further generation.

Due to disparities between low-to-medium and medium-to high class housing on respondents' early and current knowledge, further research is recommended to study this issue.

\section{REFERENCES}

Groenewegen, P. P. et al. (2006), Vitamin G: Effects of Green Space on Health, Well-Being, and Social Safety, BMC Public Health 2006, (6),149, BioMed Central, London, UK.

Kaplan, R. (2001,) The Nature of The View from Home: Psychological Benefits. Environment \& Behavior, 2001, (33), 507-542, Sage Publications, New York.

Kuo, F. E. and Sullivan, W. C. (2001-a), Aggression and Violence in The Inner City: Effects of Environment Via Mental Fatigue, Environment \& Behavior 2001, (33), 543-571, Sage Publications, New York.

Kuo, F. E. and Sullivan, W. C. (2001-b), Environment and Crime in The Inner City: Does Vegetation Reduce Crime? Environment \& Behavior 2001, 33(3), 343367, Sage Publications, New York.

Lacy, J. (1990), An Examination of Market Appreciation for Clustered Housing with Permanent Open Space, University of Massachusetts - Amherst, Department of Landscape Architecture and Regional Planning Working Paper, <http://www.unix.oit.umass.edu/ ruralma/LacyMarket.html>.

McConnell, V. and Walls, M. (2005), The Value of Open Space: Evidence from Studies of Non-Market Benefits, Research Report, Resources for The Future Washington DC, <http://www.rff.org>.

Takano, T. and Nakamura, K. (2003), Urban Residential Environments and senior Citizens' Longevity in Megacity Areas: The Importance of Walkable Green Space, J Epidemiology and Community Health 2003, (56), 913-918, BMJ Group of the British Medical Association, London, UK.

Urdan, T. C. (2010), Statistic in Plain English, Routhledge, New York. 